1 Limited specificity of SARS-CoV-2 antigen-detecting rapid diagnostic tests at

\title{
low temperatures
}

3

Verena Haage ${ }^{1}$, Andres Moreira-Soto ${ }^{1}$, Jilian A. Sacks ${ }^{2}$, Victor Corman ${ }^{1,3}$, Christian

Drosten $^{1,3}$, Felix Drexler 1,3

6

$7 \quad{ }^{1}$ Institute of Virology, Charité-Universitätsmedizin Berlin, Corporate Member of Freie

${ }^{*}$ Correspondence: Jan Felix Drexler, Helmut-Ruska-Haus, Institute of Virology, Campus Charité Mitte, Charitéplatz 1, 10098 Berlin, Germany; Email:

felix.drexler@charite.de

Keywords: SARS-CoV-2, rapid antigen tests, specificity, temperature stability, diagnostics, cold settings

NOTE: This preprint reports new research that has not been certified by peer review and should not be used to guide clinical practice. 
medRxiv preprint doi: https://doi.org/10.1101/2021.02.01.21250904; this version posted February 3, 2021. The copyright holder for this preprint (which was not certified by peer review) is the author/funder, who has granted medRxiv a license to display the preprint in It is made available under a CC-BY-NC-ND 4.0 International license

\section{Abstract}

SARS-CoV-2 antigen-detecting rapid diagnostic tests (Ag-RDTs) are available within and outside of health care settings to enable increased access to COVID-19 diagnosis. These environments include provisional testing facilities, lacking temperature control; as outside temperatures fall, recommended testing temperatures cannot be guaranteed. We report impaired specificity in two out of six Ag-RDTs when used at 2$4^{\circ} \mathrm{C}$, indicating that testing in cold settings might cause false-positive results potentially entailing unwarranted quarantine assignments and incorrect incidence estimates.

\section{Introduction}

SARS-CoV-2 antigen-detecting tests were introduced into the global market during late 2020 and are now widely used, in both the global north and south. Many regions located in the northern hemisphere such as the United States or Europe are currently severely affected by the second wave of the COVID-19 pandemic $(1,2)$. To manage testing demand many physicians, healthcare and public health systems have opened external testing stations such as 'diagnostic streets' or drive-through facilities in urban settings (3). In Berlin, a German metropolis with a population of about 3.5 million inhabitants, several outside testing stations in tents or pavilions are in use, produced by manufacturers who offer special corona test cabins (4). These facilities are often of provisional nature, for example in the form of unheated tents. In the winter months, temperatures in Europe or the U.S. can range from $-10^{\circ} \mathrm{C}$ to $10^{\circ} \mathrm{C}(5,6)$, well below the recommended operating temperatures of most Ag-RDTs. Most manufacturers of SARS-CoV-2 Ag-RDTs specify storage conditions between $2-30^{\circ} \mathrm{C}$, but stipulate that tests be equilibrated to room temperature $\left(15-30^{\circ} \mathrm{C}\right)$ at the time of use to guarantee their performance. With temperatures around freezing point during the winter months, unheated testing facilities cannot always comply with these conditions. Moreover, as 
medRxiv preprint doi: https://doi.org/10.1101/2021.02.01.21250904; this version posted February 3, 2021. The copyright holder for this preprint (which was not certified by peer review) is the author/funder, who has granted medRxiv a license to display the preprint in It is made available under a CC-BY-NC-ND 4.0 International license .

53 the national COVID-19 reference laboratory in Germany, we were contacted by

54 physicians from two German metropolis both reporting an unusual high number of positive SARS-CoV-2 Ag-RDTs from outside testing facilities. To test whether operation of SARS-CoV-2 Ag-RDTs at low outside temperatures impacts their performance, we selected six (Table 1) out of the 139 currently commercially available SARS-CoV-2 Ag-RDTs (7) based on clinical performance data (8) and market availability, for validation of specificity when stored and/or operated at cold outside temperatures of $2-4^{\circ} \mathrm{C}$.

\section{Materials and Methods}

Tested conditions included: (a) storage and testing of $\mathrm{Ag}$-RDTs at recommended conditions $\left(15-30^{\circ} \mathrm{C}\right)$; (b) storage of tests at recommended conditions, pre-incubation of tests for $30 \mathrm{mins}$ to cold-temperatures $\left(2-4^{\circ} \mathrm{C}\right)$ and testing at cold temperatures (2$4^{\circ} \mathrm{C}$ ); and (C) and storage of tests at $2-4^{\circ} \mathrm{C}$ followed by testing at $2-4^{\circ} \mathrm{C}$ (Figure 1A). Analytical specificity was examined by testing for cross-reactivity with common cell culture-derived respiratory viruses including the ubiquitous human coronaviruses

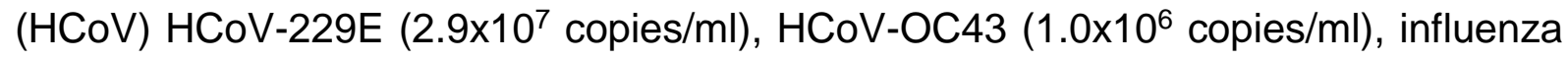
virus A H1N1 $\left(7.8 \times 10^{6}\right.$ copies $\left./ \mathrm{ml}\right)$ and rhinovirus A $\left(2.2 \times 10^{6}\right.$ copies $\left./ \mathrm{ml}\right)$. Concentrations were selected according to the guidelines on analytical specificity testing for SARSCoV-2 Ag-RDTs published by the German Federal institute for vaccines and biomedicines (9). $20 \mu$ l of viral cell culture supernatant were added to proprietary lysis buffer or as an internal control, and $20 \mu \mathrm{l}$ of lysis buffer were directly applied to test cassettes for validation experiments. Tests were performed in duplicates, according to the test-specific supplier instructions for use and results were scored independently by two persons. We additionally tested ten healthy laboratory members who previously volunteered for a SARS-CoV-2 Ag-RDT validation study (8). Healthy volunteers were 
medRxiv preprint doi: https://doi.org/10.1101/2021.02.01.21250904; this version posted February 3, 2021. The copyright holder for this preprint (which was not certified by peer review) is the author/funder, who has granted medRxiv a license to display the preprint in It is made available under a CC-BY-NC-ND 4.0 International license .

without symptoms of respiratory tract infection and tested negative for SARS-CoV-2 by RT-qPCR (10). All subjects received instructions on self-sampling, swabs were immediately dissolved in $1 \mathrm{ml}$ PBS and $20 \mu$ l of PBS were added to proprietary buffer for testing. In a recent study, self-sampling was shown to be a reliable alternative to professional nasopharyngeal swabs for Ag-RDTs (11).

\section{Results}

Two of the six SARS-CoV-2 Ag-RDTs showed impaired specificity (Figure 1B) when stored at room temperature, but exposed to $2-4^{\circ} \mathrm{C}$ for 30 minutes prior to testing at 2$4^{\circ} \mathrm{C}$ as cross-reactivity with common respiratory viruses, and false-positive results occurred in healthy volunteers in the form of weak, but clearly visible bands (Figure 1C). In one test (test I), unspecific reactivity was only observed upon short-term incubation at $2-4^{\circ} \mathrm{C}$ followed by test operation at $2-4^{\circ} \mathrm{C}$, but not after long-term storage at $2-4^{\circ} \mathrm{C}$. In contrast, the other test yielding unspecific results (test II) yielded almost identically unspecific results after both, short- and long-term storage at $2-4^{\circ} \mathrm{C}$ and operation at $2-4^{\circ} \mathrm{C}$ (Figure 1B). On the one hand, those data highlight differences between test devices. On the other hand, our results may hint at effects of relatively rapid temperature changes on some tests for unknown reasons, potentially including environmental factors such as condensation. Results were reproducible and functionality of tests was confirmed by determining their level of detection using serial dilutions of SARS-CoV-2 nucleoprotein (SARS-CoV-2-N) at recommended conditions as previously described (8).

\section{Discussion}

Our study highlights that specificity of SARS-CoV-2 Ag-RDTs may be impaired when operating tests at temperatures that differ from recommended conditions $\left(15-30^{\circ} \mathrm{C}\right)$, 
medRxiv preprint doi: https://doi.org/10.1101/2021.02.01.21250904; this version posted February 3, 2021. The copyright holder for this preprint (which was not certified by peer review) is the author/funder, who has granted medRxiv a license to display the preprint in It is made available under a CC-BY-NC-ND 4.0 International license .

105 leading to false-positive results. These results were observed for only certain test brands including one of the Ag-RDT currently listed for emergency use by the World Health Organization $(12,13)$, highlighting that each test may need to be considered specifically and broader validation of temperature robustness of SARS-CoV-2 RDTs should be performed. Moreover, impaired sensitivity of SARS-CoV-2 Ag-RDTs at elevated temperatures has been reported previously (14), highlighting the importance of test operation at recommended temperatures. Of note, all tests studied here were shown to be highly specific when operated at recommended conditions in prior studies $(8,14)$, underlining that impaired specificity is not a test-intrinsic problem but owed to test operation under conditions beyond those defined by the manufacturer. Our data imply that caution must be taken when offering SARS-CoV-2 Ag-RDT diagnostics in settings lacking temperature control, including diagnostic streets or drive-through testing stations in car parks (3). Especially under provisional conditions when minimally-trained or unexperienced staff perform diagnostic tests, the establishment of laboratory workflows and compliance with the conditions recommended by the manufacturer are vital to ensure accurate testing (15). Until January $14^{\text {th }} 2021$, severity of regional lockdown measures in Germany is increased upon trespassing 7-day incidences of 200 per 100.000 inhabitants (16), highlighting the potential consequences of false-positive test results beyond potentially unwarranted individual quarantine assignments, if those results were reported to public health authorities without confirmation by a gold standard test such as RT-PCR (10). 
medRxiv preprint doi: https://doi.org/10.1101/2021.02.01.21250904; this version posted February 3, 2021. The copyright holder for this preprint (which was not certified by peer review) is the author/funder, who has granted medRxiv a license to display the preprint in It is made available under a CC-BY-NC-ND 4.0 International license.

131 Funding

132 The study was partially supported by the Foundation for Innovative New Diagnostics

133 (FIND), including procurement of some test kits. The findings and conclusions 134 contained within are those of the authors and do not necessarily reflect positions or 135 policies of FIND.

137 Conflict of interest: The authors declare no conflict of interest. 
medRxiv preprint doi: https://doi.org/10.1101/2021.02.01.21250904; this version posted February 3, 2021. The copyright holder for this preprint (which was not certified by peer review) is the author/funder, who has granted medRxiv a license to display the preprint in It is made available under a CC-BY-NC-ND 4.0 International license.

Table 1. Overview of SARS-CoV-2 rapid antigen tests included in the study

\begin{tabular}{clll}
\hline ID & Test & Manufacturer & Lot No. \\
\hline I & Panbio ${ }^{\text {TM }}$ COVID-19 Ag Rapid Test & Abbott Laboratories & 41ADF012A \\
\hline II & $\begin{array}{l}\text { ActivXpress + COVID-19 Antigen } \\
\text { Complete Testing Kit }\end{array}$ & Edinburgh Genetics & AG20200905 \\
\hline III & COVID-19 Ag & Genedia & 643X2005 \\
\hline IV & ichroma - COVID-19 Ag & Boditech Med & SRQHA27 \\
\hline V & COVID-19 Antigen Rapid Test Kit & JOYSBIO (Tianjin) & 2020092409 \\
& & Biotechnology Co., & \\
& & Ltd. & \\
\hline VI & SARS-CoV-2 Rapid Antigen Test & Roche Diagnostics* & QCO3020083 \\
& & & QCO390003I/Sub:I-2 \\
& & & QCO390011A/Sub:A-2 \\
\hline
\end{tabular}


medRxiv preprint doi: https://doi.org/10.1101/2021.02.01.21250904; this version posted February 3, 2021. The copyright holder for this preprint (which was not certified by peer review) is the author/funder, who has granted medRxiv a license to display the preprint in It is made available under a CC-BY-NC-ND 4.0 International license
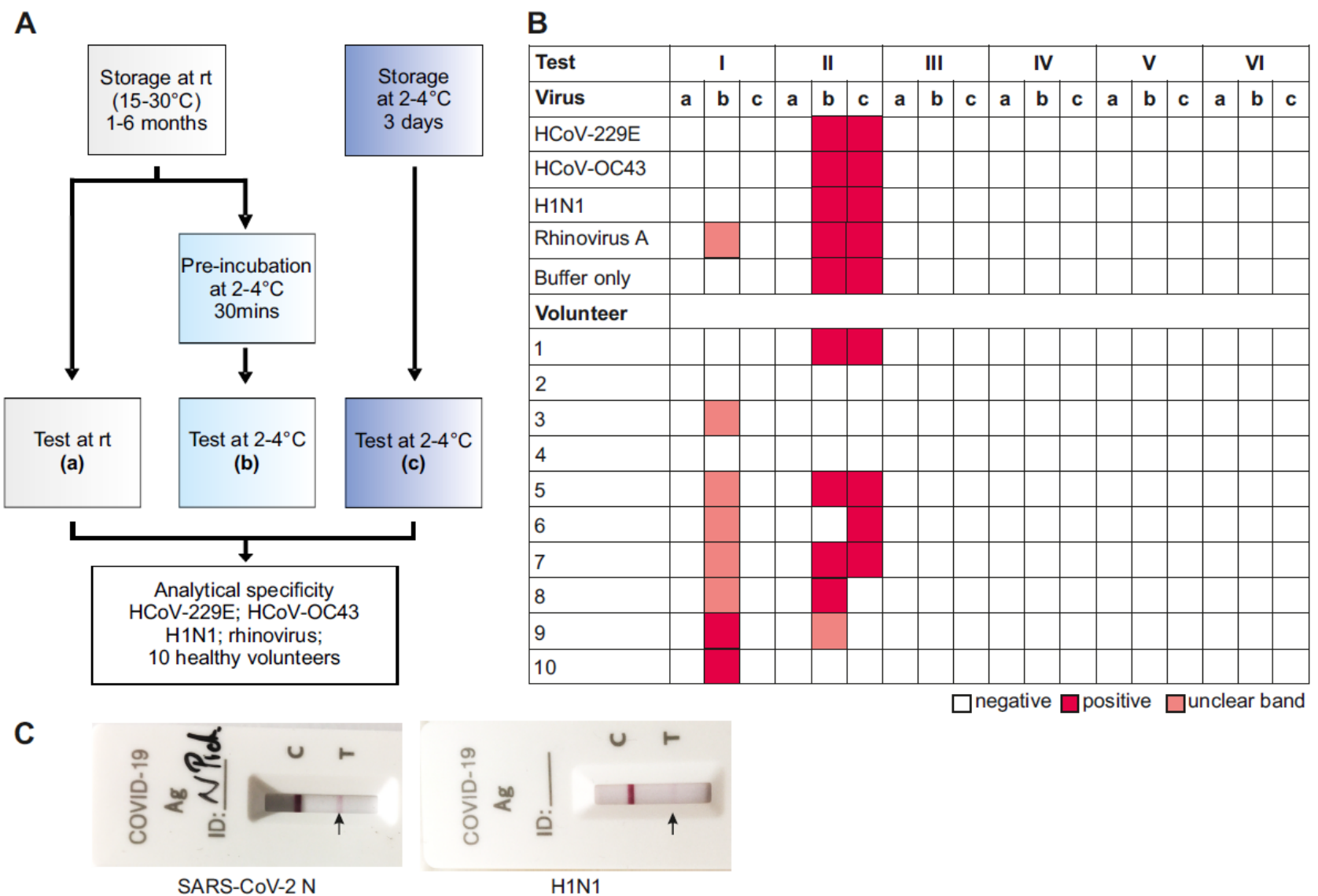

Figure 1. Experimental setup and results for specificity testing of SARS-CoV-2

Ag-RDTs. A. (a): storage and operation at recommended conditions; (b):

recommended storage, pre-incubation at $2-4^{\circ} \mathrm{C}$ for 30 mins and operation at $2-4^{\circ} \mathrm{C}$; (c):

storage and operation at $2-4^{\circ} \mathrm{C}$. B. Specificity of SARS-CoV-2 Ag-RDTs decreases at incubation $-2-4^{\circ} \mathrm{C}$ testing; (c): $2-4^{\circ} \mathrm{C}$ storage $-2-4^{\circ} \mathrm{C}$ testing. red: positive; white: negative; salmon: weak band, result unclear. rt: room temperature. I: Abbott; II: ActivXpress; III: Genedia; IV: ichroma; V: JOYSBIO; VI: Roche. C. Example for observed cross-reactivity of the ActivXpress test with Influenza virus A H1N1 and SARS-CoV-2 nucleoprotein as positive control (SARS-CoV-2-N; $5 \mu \mathrm{g} / \mathrm{ml}$ ) when tested under condition (b): recommended storage, pre-incubation at $2-4^{\circ} \mathrm{C}$ for $30 \mathrm{mins}$ and operation at $2-4^{\circ} \mathrm{C}$. 
medRxiv preprint doi: https://doi.org/10.1101/2021.02.01.21250904; this version posted February 3, 2021. The copyright holder for this preprint (which was not certified by peer review) is the author/funder, who has granted medRxiv a license to display the preprint in It is made available under a CC-BY-NC-ND 4.0 International license .

\section{References}

187

188

189

190

191

192

193

194

195

196

197

198

199

200

201

202

203

204

205

206

207

208

209

210

211

212

213

214

215

216

217

218

219

220

221

222

223

224

225

226

1. https://coronavirus.jhu.edu/us-map. Accessed 14.01.2021.

2. $\quad$ https://www.ecdc.europa.eu/en/cases-2019-ncov-eueea. Accessed 14.01.2021.

3. Shah A, Challener D, Tande AJ, Mahmood M, O'Horo JC, Berbari E, Crane SJ. 2020. DriveThrough Testing: A Unique, Efficient Method of Collecting Large Volume of Specimens During the SARS-CoV-2 (COVID-19) Pandemic. Mayo Clinic Proceedings 95:1420-1425.

4. https://www.dwd.de/DE/wetter/vorhersage_aktuell/berlin_brandenburg/vhs_bbb_node.html. Accessed 11.01.2021.

5. https://climate.copernicus.eu/european-temperature. Accessed 14.01.2021.

6. https://www.ncdc.noaa.gov/climate-information/statistical-weather-and-climateinformation. Accessed 14.01.2021.

7. https://www.finddx.org/covid-19/pipeline. Accessed 13.01.2021.

8. Corman VM, Haage VC, Bleicker T, Schmidt ML, Mühlemann B, Zuchowski M, Jó Lei WK, Tscheak P, Möncke-Buchner E, Müller MA, Krumbholz A, Drexler JF, Drosten C. 2020. Comparison of seven commercial SARS-CoV-2 rapid Point-of-Care Antigen tests. medRxiv doi:10.1101/2020.11.12.20230292:2020.11.12.20230292.

9. Sinne ABMfS-C-Ai, Antigenschnelltests. vAST.

10. Corman VM, Landt O, Kaiser M, Molenkamp R, Meijer A, Chu DK, Bleicker T, Brünink S, Schneider J, Schmidt ML, Mulders DG, Haagmans BL, van der Veer B, van den Brink $S$, Wijsman L, Goderski G, Romette J-L, Ellis J, Zambon M, Peiris M, Goossens H, Reusken C, Koopmans MP, Drosten C. 2020. Detection of 2019 novel coronavirus (2019-nCoV) by realtime RT-PCR. Eurosurveillance 25:2000045.

11. Lindner AK, Nikolai O, Kausch F, Wintel M, Hommes F, Gertler M, Krüger L, Gaeddert M, Tobian F, Lainati F, Köppel L, Seybold J, Corman VM, Drosten C, Hofmann J, Sacks JA, Mockenhaupt FP, Denkinger CM. 2020. Head-to-head comparison of SARS-CoV-2 antigendetecting rapid test with self-collected anterior nasal swab versus professional-collected nasopharyngeal swab. medRxiv doi:10.1101/2020.10.26.20219600:2020.10.26.20219600.

12. https://www.who.int/diagnostics_laboratory/eual/listing/en/. Accessed 14.01.2021.

13. https://www.who.int/diagnostics_laboratory/200922_eul_sars_cov2_product_list.pdf?ua=1. Accessed 14.01.2021.

14. Haage V, de Oliveira-Filho EF, Moreira-Soto A, Kühne A, Fischer C, Sacks J, Corman VM, Müller MA, Drosten C, Drexler JF. 2021. Impaired performance of SARS-CoV-2 antigendetecting rapid tests at elevated temperatures. medRxiv doi:10.1101/2021.01.06.21249314:2021.01.06.21249314.

15. Fischer C, Mögling R, Melidou A, Kühne A, Oliveira-Filho EF, Wolff T, Reiche J, Broberg E, Meijer A, Leitmeyer K, Drexler JF, Reusken C. 2020. Variable sensitivity in molecular detection of SARS-CoV-2 in European Expert Laboratories: External Quality Assessment, June - July 2020. J Clin Microbiol doi:10.1128/jcm.02676-20.

16. https://www.bundesregierung.de/breg-de/themen/coronavirus/corona-massnahmen1734724. Accessed 14.01.2021. 